\title{
The Effect of Magnetic Induction on Seeds Infected Fusarium Sp. Toward Generative Growth of Red Chili (Capsicum annuum. L)
}

\author{
Rochmah Agustrina*, Berekhya Glori Hernawati, Yulianti, dan Bambang Irawan \\ Jurusan Biologi Fakultas Matematika dan Ilmu Pengetahuan Alam Universitas Lampung \\ JI. Prof. Soemantri Brodjonegoro, No 1, Bandar Lampung 35145 \\ *Email: rochmah.agustrina@fmipa.unila.ac.id
}

\begin{abstract}
Magnetic fields are proven to improve the quality of growth of various plants. In the study, it was examined whether the treatment of magnetic fields on chili seeds (Capsicum annuum. $\mathrm{L}$ ) infected by Fusarium sp. could maintain plant growth to the generative phase. This research is two-factor research using a randomized block design. The first factor is the 0.2 mT magnetic field induction treatment consisting of 7 minutes 48 seconds (M7), 15 minutes 36 seconds (M15) and control (M0) as control and the second factor is the Fusarium oxysporum infection treatment consisting of 60 minutes infected (F60) and not infected (F0). Each treatment unit was repeated 5 times. Data obtained were analyzed for variance at a $5 \%$ significance level. The results of the analysis showed that the treatments in this study did not provide significant differences in carbohydrate content, flowering speed and number of flowers, as well as the fruiting rate of plants from seeds infected with Fusarium sp (M0F60, $\mathrm{M7}, \mathrm{F} 60$, and M15F60), thus the magnetic field treatment could be causing plants to be resistant to Fusarium sp. so plants from seeds infected with Fusarium sp. able to flower and bear fruit at the same speed and produce the same amount of interest
\end{abstract}

Keywords: magnetic fields, Fusarium sp. seed

\section{PENDAHULUAN}

Cabai merah (Capsicum annuum L.) termasuk tanaman holtikultura yang banyak diminati karena dapat digunakan untuk berbagai keperluan baik untuk industri maupun keperluan rumah tangga. Permintaan yang terus meningkat terhadap cabai merah menyebabkannya menjadi salah satu produk holtikultura yang bernilai ekonomi tinggi. Walaupun demikian hasil produksi cabai merah masih fluktuatif selama beberapa tahun terakhir. Kendala yang ditemui petani cabai salah satunya adalah serangan penyakit tanaman cabai, yaitu layu fusarium yang disebabkan oleh jamur patogen Fusarium oxysporum (Herlina, 2009).

Penyakit layu fusarium pada tanaman disebabkan oleh jamur Fusarium sp. Jamur Fusarium sp. dapat menginfeksi baik pada tanaman muda maupun tanaman dewasa. Gejala terserang penyakit layu fusarium adalah layu pada tanaman, kerusakan pada jaringan pembuluh, epinasti, kerdil dan penguningan pada daun yang lebih tua. Gejala ini disebabkan karena adanya reaksi sistemik pada tanaman yang akhirnya menyebabkan kematian pada tanaman terinfeksi (Ferniah dkk., 2014). Menurut Agrios (2005) pertumbuhan miselium Fusarium oxysporum diawali pada korteks akar hingga mencapai pembuluh xilem, sehingga transport air dan unsur hara dari akar ke bagian tanaman di atasnya, seperti daun menjadi terhambat. Rusaknya pembuluh xilem karena infeksi Fusarium oxysporum pada tomat diketahui menyebabkan terhambatnya transportasi air dan unsur hara ari akar ke daun sehingga proses fotosintesis terganggu dan menyebabkan proses transisi dari fase vegetatif ke generatif menjadi terhambat (Susanna dkk., 2009). Pengendalian layu fusarium saat ini umumnya menggunakan fungisida. Penggunaan fungisida dalam 
jangka waktu panjang dapat menyisakan residu di lingkungan sehingga tidak ramah lingkungan. Perlu upaya lain untuk mengatasi jamur patogen yang lebih ramah lingkungan, salah satunya dengan pemanfaatan medan magnet.

Penelitian sebelumnya menunjukkan bahwa medan magnet diketahui dapat meningkatkan pertumbuhan tanaman. Medan magnet diketahui dapat meningkatkan permeabilitas membran serta konsentrasi unsur hara seperti : $\mathrm{N}$, $\mathrm{K}, \mathrm{Ca}, \mathrm{Mg}, \mathrm{Cu}, \mathrm{Fe}, \mathrm{Mn}, \mathrm{Na}$ dan $\mathrm{Zn}$ pada daun strawberry (Fragaria $x$ ananassa) (Esitken dan Turan, 2003), dan presentasi perkecambahan benih Pinus tropicalis $\mathrm{M}$. (Morejon dkk., 2007), meningkatkan kandungan lipid pada biji kedelai (Radhakrishnan,2017), pertumbuhan generatif tomat, dan berpengaruh nyata terhadap kandungan klorofil total serta karbohidrat (Rivera,2018). Induksi medan magnet juga diketahui dapat berpengaruh nyata terhadap kecepatan pembentukan bunga, berat buah, dan kandungan vitamin $\mathrm{C}$ tomat yang ditumbuhkan dari benih tomat yang diinfeksi Fusarium oxysporum dengan (Listiana, 2016), dan meningkatkan aktivitas enzim peroksidase (Nastiti, 2017).

Setiap tanaman memberikan respon yang berbeda terhadap medan magnet, tergantung pada jenis dan umur tanaman dan kuat serta lama medan magnet yang diberikan (Agustrina, et al., 2012). Penelitian ini bertujuan untuk mengetahui pengaruh pemberian medan magnet pada pertumbuhan dan produksi generatif benih cabai yang diinfeksi Fusarium sp.

\section{METODE PENELITIAN}

\section{Tempat dan Waktu}

Penelitian dilaksanakan di Laboratorium Lapang Terpadu Fakultas Pertanian Universitas Lampung, Laboratorium Mikrobiologi dan Laboratorium Botani Jurusan Biologi Fakultas Matematika dan IImu Pengetahuan Alam Universitas Lampung dari Januari 2019 sampai April 2019.

\section{Perlakuan Induksi Medan Magnet}

Benih cabai kultivar lado F1 yang telah diseleksi dan direndam dalam akuades selama 15 menit sebelum diberi perlakuan medan magnet 0,2 $\mathrm{mT}$. Perlakuan induksi medan magnet pada benih cabai dibagi atas tiga kelompok perlakuan yaitu diinduksi selama 7 menit 48 detik (M7), 15 menit 36 detik (M15) dan kontrol (M0) (Listiana, 2016). Sumber medan magnet yang digunakan adalah solenoida yang sudah diatur sedemikian rupa sehingga dapat menghasilkan kuat medan magnet $0,2 \mathrm{mT}$.

\section{Perlakuan Infeksi Jamur Fusarium oxysporum}

Isolat Fusarium oxysporum (Fox) yang digunakan diperoleh dari SEAMEO BIOTROP Bogor. Infeksi jamur Fusarium sp. pada benih dibagi ke dalam dua kelompok yaitu kelompok benih tanpa perlakuan infeksi jamur Fox (F0) dan kelompok dengan perlakuan infeksi jamur Fox pada benih (F60). Infeksi jamur Fox dilakukan dengan merendam benih capai dalam suspensi spora jamur Fox dengan kerapatan spora $10^{7} \mathrm{konidia}$ sel $/ \mathrm{ml}$ selama 60 menit (Listiana, 2016).

\section{Penyemaian dan Penanaman}

Benih yang telah diberi perlakuan induksi medan magnet 0,2 mT dan infeksi Fox dikecambahkan pada cawan petri yang telah dilapisi kertas germinasi basah sampai menghasilkan kecambah yang memiliki panjang radikula $\pm 0,5 \mathrm{~cm}$. Kemudian kecambah tersebut disemai dalam polybag kecil berisi media tanam yang telah disterilisasi. Media tanam yang digunakan adalah campuran tanah dan kompos dengan perbandingan 3:1. Semaian disimpan di tempat yang cukup cahaya matahari namun tidak terik selama 7 hari, sampai terbentuk bibit cabai dengan tinggi tunas $\pm 2-3 \mathrm{~cm}$. Bibit ditanam pada polybag berisi sekitar $10 \mathrm{~kg}$ media tanam steril. Pemeliharaan tanaman meliputi pemupukan, penyiraman, dan penyiangan tanaman gulma yang dilakukan mengikuti cara yang lazim dilakukan oleh petani cabai.

\section{Rancangan penelitian}

Penelitian ini merupakan penelitian faktorial dengan dua faktor yang disusun menggunakan rancangan acak kelompok. Faktor pertama adalah perlakuan induksi medan magnet 0,2 $\mathrm{mT}$ dan faktor kedua 
adalah perlakuan infeksi Fusarium oxysporum (Fox) dengan level masing masing perlakuan seperti dijelaskan di atas. Setiap unit perlakuan diulang 5 kali. Data yang diperoleh dianalisi varians pada $\alpha=5 \%$ dan bila perlakuan menghasilkan pengaruh yang berbeda nyata dilanjutkan dengan uji beda antar perlakuan menggunakan Uji Tukey pada taraf nyata (a) yang sama.

\section{Pengambilan Data Kecepatan pembentukan bunga dan buah serta jumlah bunga yang terbentuk}

Data kecepatan pembentukan bunga dan buah ditentukan berdasarkan hari pertama mulai terlihatnya kuncup bunga dan bakal buah pertama terlihat. Jumlah bunga yang terbentuk dihitung pada hari ke-63 setelah tanam (hst). Bunga yang dihitung termasuk kuncup bunga yang mulai terbentuk.

\section{Analisis Kandungan Karbohidrat}

Analisis kandungan karbohidrat dilakukan pada 28 dan 49 (HST) dengan mengikuti metode yang digunakan oleh Apriyantono et al. (1989). Sebanyak 0,1 gram sampel daun tanaman dihaluskan dan dilarutkan dalam $10 \mathrm{ml}$ aquades lalu disaring menggunakan kertas saring. Selanjutnya ke dalam $1 \mathrm{ml}$ larutan sampel ditambahkan $2 \mathrm{ml}$ akuades sebelum ditambahkan $2 \mathrm{ml} \mathrm{H}_{2} \mathrm{SOH}$ pekat dan $1 \mathrm{ml}$ larutan Fenol 5\%. Larutan sampel kemudian dihomogenkan kemudian didiamkan selama beberapa menit sebelum dilakukan pengukuran kandungan karbohidrat. Kandungan karbohidrat diukur menggunakan spektrofotometer-UV pada panjang gelombang $490 \mathrm{~nm}$.

\section{HASIL DAN PEMBAHASAN}

Respon pertumbuhan generatif taanaman cabai yang diinduksi medan magnet 0,2 mT (M) dan infeksi Fusarium oxysporum (Fox) (F) diamati pada parameter kandungan karbohidrat, kecepatan pembentukan dan jumlah bunga serta kecepatan pembentukan buah. Hasil analisis data pada taraf nyata 5\% diperoleh bahwa perlakuan induksi medan magnet 0,2 mT (M), infeksi Fox $(F)$, dan perlakuan interaksi antara induksi medan magnet 0,2 mT dan infeksi Fox (MF) tidak memberikan pengaruh yang nyata terhadap semua parameter yang diukur. Dengan demikian pembahasan dilakukan secara deskriptif berdasarkan nilai ratarata yang diperoleh.

Perlakuan interaksi induksi medan magnet 0,2 $\mathrm{mT}$ dan infeksi Fox (MF) tidak mempengaruhi kecepatan pembentukan bunga. Kecepatan pembentukan bunga terjadi serentak pada 30 hst (Gambar 1). Perlakuan interaksi antara induksi medan magnet 0,2 mT dan infeksi Fox (MF) juga tidak mempengaruhi kandungan karbohidrat baik pada fase vegetatif maupun generatif. Hasil di atas menunjukkan bahwa induksi medan magnet 0,2 $\mathrm{mT}$ mampu mempertahan kandungan karbohidrat tanaman sehingga infeksi Fox tidak menyebabkan penurunan kandungan karbohidrat baik pada fase vegetatif maupun fase generatif. Induksi medan magnet 0,2 $\mathrm{mT}(\mathrm{M})$ pada benih cabai diduga mampu meningkatkan metabolisme pertumbuhan tanaman cabai yang dihasilkannya sehingga tanaman dapat mempertahankan pertumbuhan terhadap serangan jamur Fusarium oxysporum (Fox) yang diinfeksikan pada benih. Dugaan ini diperkuat dengan hasil penelitian yang menunjukkan bahwa perlakuan medan magnet pada tanaman kentang (Hozayn dkk., 2016), tomat (Rivera, 2018), dan padi (Babaloo dkk., 2019) meningkatkan kandungan karbohidrat. Pemaparan medan magnet pada benih cabai yang diifeksi Fox mampu mempertahankan pertumbuhan tanaman tomat bahkan mempertahankan produksi cabai yang dihasilkannya.

Dari Gambar 1 di atas diketahui bahwa kandungan karbohidrat tanaman cabai dari benih kontrol (MOF0) serta benih yang diinduksi medan magnet $0,2 \mathrm{mT}$ selama 7 menit 48 detik dan diinfeksi Fox (M7F60) pada fase generatif menurun relatif cukup tinggi dari kandungan karbohidrat pada fase vegetatifnya. Pada Gambar 2 kemudian diketahui bahwa kedua perlakuan tersebut menghasilkan jumlah bunga yang relatih lebihb anyak dibandingkan perlakuan lainnya. Dengan demikian, penurunan kandungan karbohidrat pada fase generatif pada 
kedua perlakuan tersebut ini diduga terkait dengan jumlah bunga yang terbentuk. Karbohidrat sebagai hasil metabolit utama merupakan sumber energi yang penting bagi aktivitas tumbuh kembang tanaman termasuk untuk proses pembentukan bunga (Tognetti dkk., 2013).

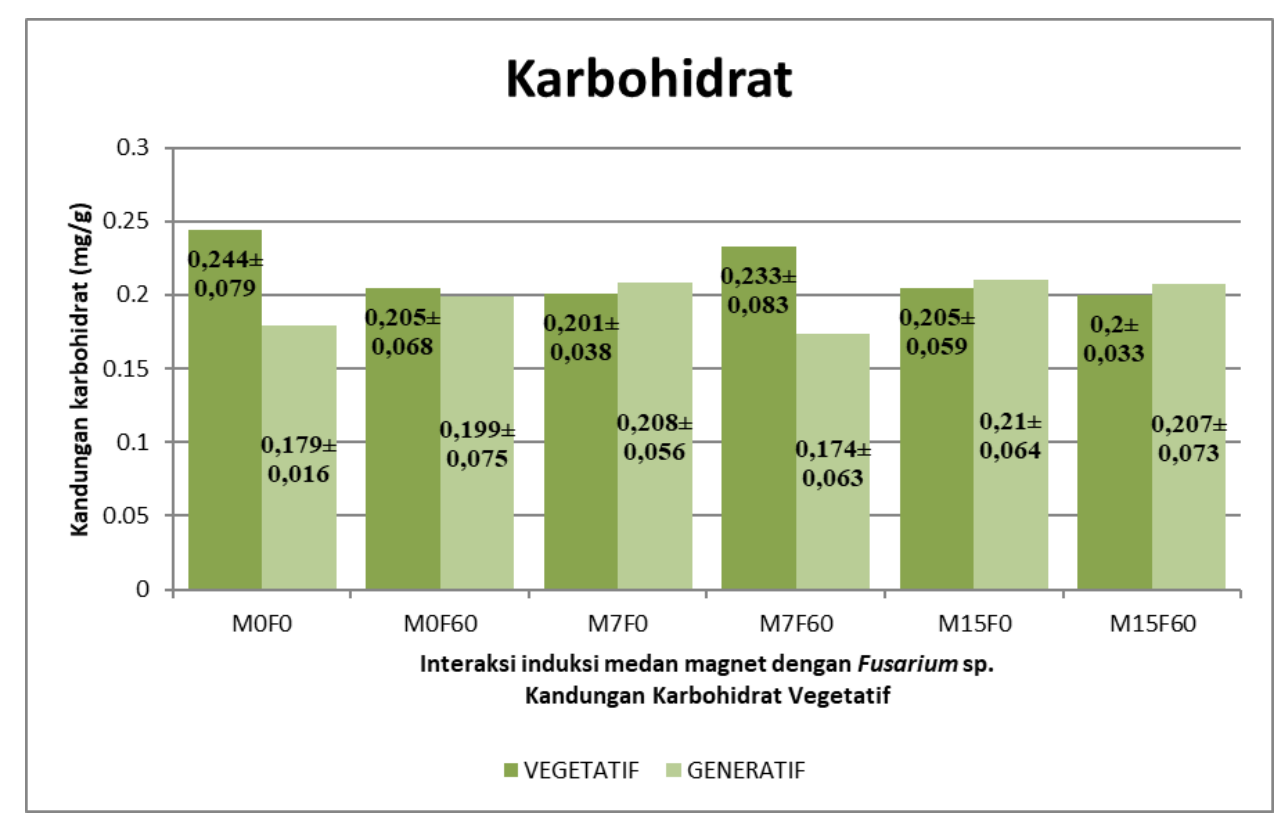

Gambar 1. Pengaruh interaksi induksi medan magnet (M) dengan infeksi Fusarium sp. (Fox) terhadap kandungan karbohidrat yang diukur pada fase vegetatif (sebelum berbunga) dan fase generatif (setelah berbunga). $M=$ induksi medan magnet $0,2 \mathrm{mT} ; \mathrm{F}=$ infeksi Fox; $0=$ tanpa perlakuan, $7=7$ menit 48 detik; $15=15$ menit 36 detik, dan $60=60$ menit.

Pada tanaman cabai dari benih kontrol yang diinfeksi Fox (MOF60) dan benih yang diinduksi medan magnet 0,2 $\mathrm{mT}$ selama 7 menit 48 detik tanpa dinfeksi Fox (M7F0) menunjukkan kandungan karbohidrat tanaman pada fase vegetatif dan generatif relatif sama (Gambar 1) dan jumlah bunga yang dihasilkannya sedikit (Gambar 2). Sedangkan pada tanaman dari benih yang diinduksi medan magnet $0,2 \mathrm{mT}$ selama 15 menit 36 detik baik yang tidak diinfeksi (M15F0) dan yang diinfeksi Fox (M15F60) tidak menunjukkan adanya perubahan kandungan karbohidrat dari fase vegetatif ke fase generatif namun jumlah bunga yang dihasilkannya reatif banyak banyak seperti pada tanaman dari perlakuan M0F0 dan M7F60.

Pengaruh induksi medan magnet pada benih diketahui dapat mengubah kadar ion $\mathrm{Ca}^{2+}$ dalam sel-sel biji sehingga kemudian mengakibatkan terjadinya perubahan tekanan osmosis dan kapasitas sel untuk menyerap air. Peningkatan penyerapan air dalam sel biji memicu peningkatan aktivitas enzim perkecambahan, salah satunya adalah enzim $\alpha$-amilse sehingga meningkatkan laju germinasi (Handoko dkk., 2017). Menurut Ai dan Ballo (2010) serta Haryanti dan Budihastuti (2015)

adanya peningkatan laju imbibisi air ke dalam biji mempecepat aktivitas enzim perkecambahan untuk mulai menguraikan simpanan cadangan makanan dalam endosperma dan bersama dengan nutrien lainnya hasil penguraian cadangan makanan ditransfer menuju bagian embrio yang sedang tumbuh, membentuk individu baru hingga akhirnya mampu melakukan fotosintesis. Ketersediaan fotosintat pada bagian tajuk tanaman menyebabkan terstimulasinya pembentukan bunga (Liferdi dkk., 2005).

Hasil pada $\alpha=5 \%$ menunjukkan bahwa interaksi antara induksi medan magnet dan infeksi Fox mempengaruhi jumlah bunga yang terbentuk yang dihitung pada 63 hari setelah tanam (hst). Penurunan jumlah bunga secara signifikan terlihat 
pada tanaman dari benih yang tidak diinduksi medan magnet $0,2 \mathrm{mT}$ dan diinfeksi Fox (M0F60). Penurunan jumlah bunga yang dihasilkan juga diperoleh dari tanaman yang berasal dari benih yang diinduksi medan magnet $0,2 \mathrm{mT}$ selama 15 menit 36 detik dan diinfeksi Fusarium oxysporum (M15F60) dibandingakan dari benih yang tanpa infeksi Fox (M15F0). Namun demikian data yang sebaliknya justru diperoleh dari tanaman yang berasal dari benih yang diinduksi medan magnet $0,2 \mathrm{mT}$ selama 7 menit 48 detik dimana jumlah bunga pada benih yang diinfeksi Fox (M7F60) relatif lebih banyak dibandingan dari benih yang tanpa infeksi Fox (M7F0). Penurunan jumlah bunga akibat infeksi Fox diduga karena pertumbuhan hifa Fox pada tanaman yang benihnya diinfeksi Fox menghambat transport unsur hara dan nutrisi dalam xylem yang dibutuhkan untuk pertumbuhan dan perkembangan tanaman. Hasil penelitian Susanna dkk. (2009) menunjukkan adanya kerusakan pembuluh xilem pada tanaman tomat akibat infeksi Fusarium yang kemudian berdampak pada terganggunya transport air dari tanah ke seluruh bagian tumbuhan, sehingga pertumbuhan tanaman tidak optimal. Menurut Andayani dan Sarido (2013) penyerapan unsur hara pada tanaman sangat mempengaruhi pembentukan kuncup - kuncup bunga.

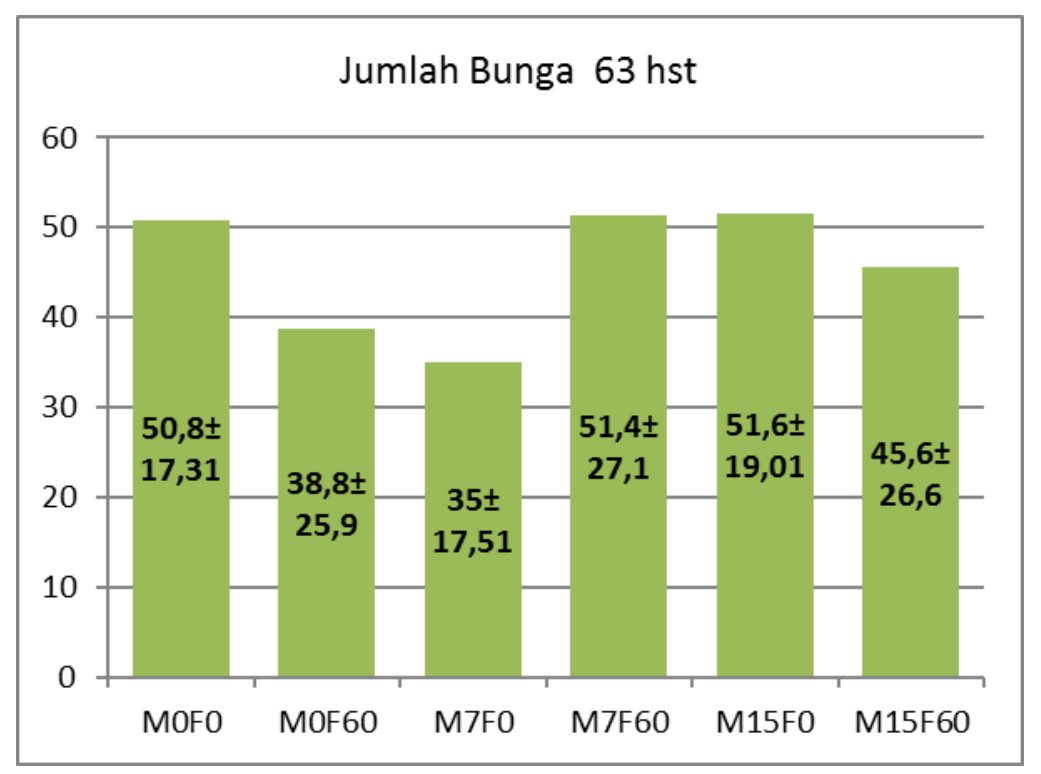

Gambar 2. Pengaruh interaksi induksi medan magnet (M) dengan infeksi Fusarium sp. (Fox) terhadap jumlah bunga pada 63 hst. $\mathrm{M}=$ induksi medan magnet $0,2 \mathrm{mT} ; \mathrm{F}=$ infeksi Fox; $0=$ tanpa perlakuan medan magnet $0,2 \mathrm{mT} ; 7=7$ menit 48 detik; $5=$ menit 36 detik, dan $60=60$ menit.

Berbeda dengan tanaman dari benih hasil perlakuan M15F60, pada tanaman dari benih M15F0 kandungan karbohidrat tanaman pada fase generatif tetap tinggi dan jumlah bunga yang dihasilkan juga banyak. Bila diamati pada rata rata kecepatan pembentukan buahnya meskipun secara anara pada $\alpha=5 \%$ tidak berbeda nyata, namun pada tanaman dari benih M15F0 relatif menunjukan pembentukan buah yang lebih cepat dibandingan tanaman dari benih hasil perlakuan lainnya (Gambar 3).
Suprapto dkk. (2019) menjelaskan bahwa hasil fotosintesis tanaman akan ditranslokasikan ke bagian lain dari tanaman tersebut baik selama proses pertumbuhan maupun perkembangan tanaman. Selama masa pertumbuhan, laju pertumbuhan tanaman selalu berubah seiring dengan waktu, hal ini disebabkan adanya pengaruh fluktuasi perubahan pada faktor lingkungan.

Pembentukan bunga merupakan hasil proses metabolisme perkembangan yang melibatkan perubahan fisiologi dan morfologi dipengaruhi sejumlah faktor 
eksternal dan internal. Faktor-faktor ekternal dan internal memicu perubahan metabolisme pada ujung - ujung meristem yang semula melangsungkan metabolisme untuk menghasilkan organ vegetatif, tunas untuk batang dan daun, kemudian bergeser menjadi metabolisme untuk proses pertumbuhan generatif yang ditandai dengan pembentukan bakal bunga (Hanke dkk., 2007). Peningkatan kandungan karbohidrat pada ujung-ujung meristem sebagai hasil mobilisasi cadangan karbohidrat dari berbagai bagian vegetatif tanaman yang disimpan dalam bentuk pati, kemudian dikonversi menjadi gula yang mudah larut dan ditranslokasikan ke jaringan tanaman yang membutuhkan. Pada jaringan meristem bakal buah, sukrosa kemudian digunakan dalam berbagai proses metabolism untuk memacu inisiasi pembentukan bunga.

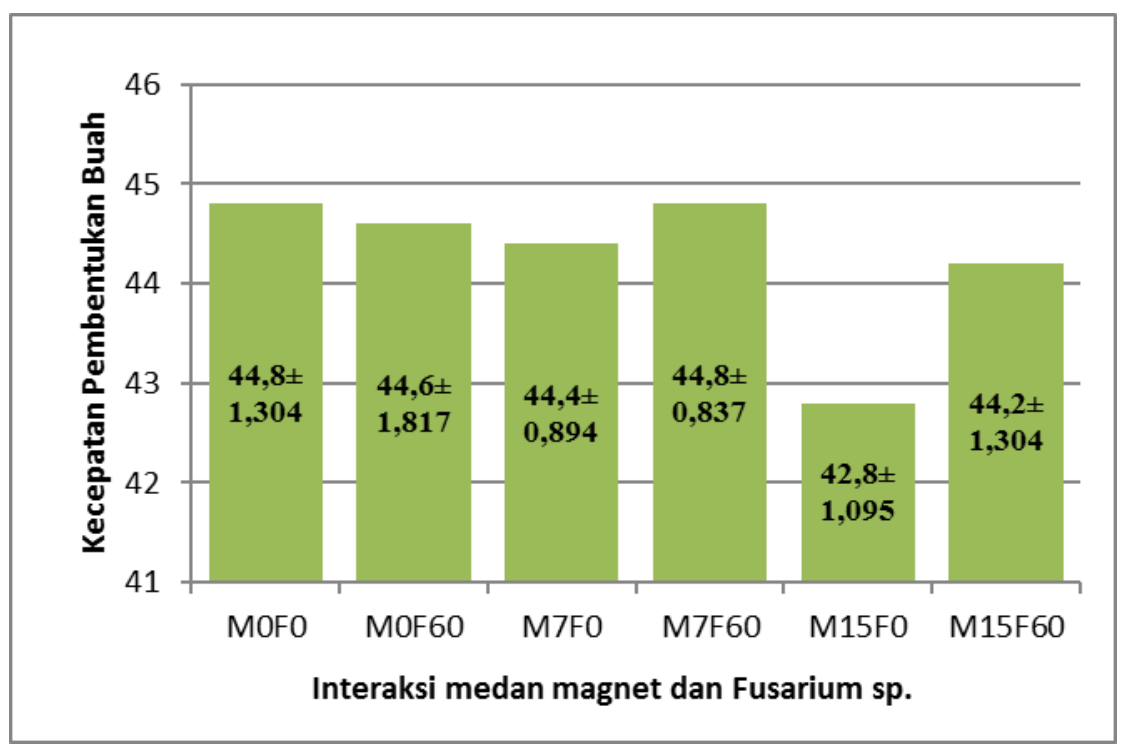

Gambar 3. Pengaruh interaksi induksi medan magnet (M) dengan infeksi Fusarium sp. (Fox) terhadap kecepatan pembentukan buah. $\mathrm{M}=$ induksi medan magnet 0,2 $\mathrm{mT} ; \mathrm{F}=$ infeksi Fox; $0=$ tanpa perlakuan medan magnet $0,2 \mathrm{mT} ; 7=7$ menit 48 detik; $15=$ menit 36 detik, dan $60=60$ menit.

Menurut Prado et al. (2007) dan Cho et al. (2018) selama berlangung proses pergeseran metabolisme dari metabolisme pertumbuhan vegetatif ke pertumbuhan generatif berlangsung koordinasi regulasi metabolisme enzim fotosintesis, enzim pemecahan sukrosa, dan transporter gula untuk mempertahankan ketersediaan kadar sukrosa tanaman yang sebagian ditranspor ke jaringan meristem apikal untuk membentuk bunga.

Rata rata pembentukan buah paling cepat diperoleh dari perlakuan induksi medan magnet M15F0. Hasil ini diduga berhubungan dengan kandungan karbohidrat tanaman pada fase generatif. Pada fase generatif kandungan karbohidrat tanaman dari benih hasil perlakuan induksi medan magnet 0,2 $\mathrm{mT}$ selama 15 menit 36 detik tanpa infeksi Fusarium oxysporum (M15F0) memiliki kandungan karbohidrat yang tertinggi, dan diduga kondisi inilah yang memicu pembentukan buah relatif lebih cepat daripada pada tanaman dari perlakuan lainnya. Menurut Prado et al. (2007) cadangan karbohidrat dalam bentuk pati akan dipecah menjadi glukosa yang kemudian digunakan untuk pembentukan bunga dan buah. Selain karbohidrat, tanaman juga memerlukan unsur hara untuk pembentukan sel-sel baru, sejumlah protein tertentu yang diperlukan dalam mengkatalis asimilasi penting untuk dapat mempercepat pembuahan dan pemasakan buah. Pertumbuhan hingga hasil produksi buah akan berhasil apabila keperluan nutrisi atau unsur hara tanaman tercukupi (Jumin, 2005). 
Lamanya kecepatan pembentukan buah pada tanaman yang diinfeksi Fusarium sp. (F) diduga disebabkan karena terhambatnya translokasi karbohidrat sehingga kecepatan pembentukan buah menjadi lebih lama. Menurut Wandani dan Rahayu ( 2015) Fusarium sp. (F) pada tanaman mengakibatkan sistem transport air dalam jaringan xilem menjadi terhambat, sehingga proses fotosintesis menjadi terganggu, jika fotosintesis terganggu maka glukosa sebagai penyusun utama buah tidak dihasilkan secara maksimal, sehingga mempengaruhi pertumbuhan buah.

Hasil pengamatan pada kandungan karbohidrat, kecepatan pembentukan dan jumlah bunga, serta kecepatan pembentukan buah dalam penelitian ini memberikan dugaan bahwa medan magnet mempengaruhi pertumbuhan tanaman cabai dari benih yang diinfeksi Fox. Induksi medan magnet pada benih mempengaruhi metabolisme tanaman yang dihasilkannya termasuk kemampuan tanaman dalam mempertahankan pertumbuhannya terhadap infeksi Fox sehingga tanaman mampu bertahan tumbuh hingga bereproduksi. Namun respon tanaman terhadap perlakuan induksi medan magnet dan infeksi Fox tidak sama untuk setiap parameter pertumbuhan generatifnya. Secara umum perlakuan medan magnet dapat mempertahankan kandungan karbohidrat tanaman sehingga kandungan karbohidrat relatif sama baik pada tanaman dari benih yang diinfeksi maupun tidak diinfeksi Fox. Ketersediaan karbohidrat dalam sel tumbuhan merupakan hal yang vital bagi pertumbuhan dan perkembangan tanaman (Liferdi dkk., 2005).

\section{KESIMPULAN}

Hasil penelitian ini membuktikan bahwa interaksi antara induksi medan magnet 0,2 $\mathrm{mT}$ dan infeksi Fusarium sp. tidak memberikan pengaruh nyata terhadap kandungan karbohidrat, kecepatan pembentukan bunga dan buah. Dengan demikian membuktikan pemberian medan magnet $0,2 \mathrm{mT}$ pada benih cabai dapat mempertahankan tanaman yang dihasilkannya terhadap serangan
Fusarium sp. yang diinfeksikan pada benih cabai.

\section{DAFTAR PUSTAKA}

Agrios, G.N. (2005). Plant Pathology. San Diego: Academic Press.

Agustrina, R., T.T.Handayani, S. Wahyuningsih, dan O. Prasetya. (2012). Pertumbuhan Tanaman Tomat (Lycopersicum esculentum Mill.) di Bawah Perlakuan Medan Magnet 0,2 mT. Prosiding SNSMAIP III. 277-281

Andayani, L.Sarido. (2013). Uji Empat Jenis Pupuk Kandang Terhadap Pertumbuhan dan Hasil Tanaman Cabai Keriting (Capsicum annuum L.). Jurnal AGRIFOR, 12(1), 22-29

Apriyantono, A., D. Fardiaz, N. L. Puspitasari, Sedamawati dan S. Budiyanto. (1989). Petunjuk Praktikum Analisis Pangan. PAU Pangan dan Gizi. Bogor: IPB Press.

Cho.L.H., R. Pasriga., J. Yoon., J.S. Jeon., G.An. (2018). Roles of Sugars in Controlling Flowering Time. Journal of Plant Biology, 61, 121-130.

Esitken.A., Turan.M. (2003). Alternating magnetic field effects on yield and plant nutrient element composition of strawberry (Fragaria $x$ ananassa cv. camarosa). Acta Agriculturae Scandinavica, Section $B-$ Soil \& Plant Science, 54, 135-139.

Babaloo, F., Ahmad Majd, Sedighe Arbabian, Fariba Sharifnia, Faeze Ghanati. (2018). The Effect of Magnetized Water on Some Characteristics of Growth and Chemical Constituent in Rice (Oryza sativa L.)Var Hashemi. EurAsian Journal of Bio Sciences, 12, 129137.

Ferniah, R..S., Daryono, B.S., Kasiamdari, R.S., Priyatmojo, A. (2014). Characterization and Pathogenicity of as the Causal Agent Fusarium oxysporum of Fusarium Wilt in Chili 
( L.). Microbiology Indonesia, 8(3), 121-126.

Handoko, Sudarti, Handayani R.D. (2017). Analisis Dampak Paparan Medan Magnet Extremly Low Frequency (ELF) Pada Biji Cabai Merah Besar (Capsicum annuum L.) Terhadap Pertumbuhan Tanaman Cabai Merah Besar (Capsicum annuum L.). Jurnal Pembelajaran Fisika, 5(4), $370-377$.

Hanke, M.-V., Flachowsky, H., Peil, A. and Hättasch, C. (2007). No flower no fruit- genetic potentials to trigger flowering in fruit trees. Genes Genomes Genomics, 1(1), 1- 20.

Haryanti.S., R. Budihastuti. (2015). Morfoanatomi, Berat Basah Kotiledon dan Ketebalan Daun Kecambah Kacang Hijau (Phaseolus vulgaris L.) pada Naungan yang Berbeda. Buletin Anatomi dan Fisiologi, 13(1), 47-56.

Herlina, L. (2009). Potensi Trichoderma harzianum sebagai Biofungisida pada Tanaman Tomat. Biosaintifika, $1,62$.

Hozayn M, Azza M Salama,Abd ElMonem AA, and Alharby F Hesham. (2016). The Impact of Magnetized Water on the Anatomical Structure, Yield and Quality of Potato (Solanum tuberosum L.) Grown Under Newly Reclaimed Sandy Soil. Research Journal of Pharmaceutical, Biological and Chemical Sciences, 7(3), 10591072.

Jumin. H. B. (2005). Dasar-dasar Agronomi (cetakan kelima). Jakarta: Raja Grafindo Perseda.

Liferdi, R. Poerwanto., L.K. Darusman. (2005). Perubahan Kandungan Karbohidrat dan Nitrogen 4 Varietas Rambutan. Jurnal Hortikultura, 16(2), 134-141

Listiana, I. (2016). Pengaruh Medan Magnet F0,2 mT Terhadap
Pertumbuhan Generatif Tanaman Tomat (Lycopersicum esculentum Mill.) Yang Diinfeksi Fusarium oxysporum (Tesis). Lampung: Universitas Lampung.

Morejon, L.P., J.C.C. Paloco., V. Abad and A.P. Govea. (2007). Stimulation of Pinus Tropicalis $\mathrm{m}$. Seeds by Magnetically Treated Water. International Agrophysics, 21, 173177.

Nastiti, E. (2017). Efektivitas Medan Magnet 0,2 mT Terhadap Vigor dan Karakter Tanaman Tomat (Lycopersicum esculentum Mill.) Yang Diinfeksi Fusarium sp (Tesis). Bandar Lampung: Universitas Lampung.

Ail, Nio Song dan Maria Ballo. (2010). Peranan Air Dalam Perkecambahan Biji. Jurnal Ilmiah Sains, 10(2), 190195.

Prado, A.K.D.S., Machado, E.C., Medina, C.L., Machado, D.F.S.P., Mazzafera, P. (2007). Flowering and fruit set in'valência'orange trees under different crop load status and with and without irrigation. Bragantia, 66, 173-182.

Radhakrishnan, R. (2017). Seed pretreatment with magnetic field alters the storage proteins and lipid profiles in harvested soybean seeds. Physiology and Molecular Biology of Plants, 24(2), 343-347.

Rivera, P.A. (2018). Pengaruh Kuat Medan Magnet Terhadap Pertumbuhan Generatif Tanaman Tomat (Lycopersicum Esculentum Mill.) Yang Berasal Dari Benih Baru Dan Benih Lama (Skripsi). Bandar Lampung: Universitas Lampung.

Suprapto.A., M. Astiningrum., H. Rianto. (2019). Optimalisasi Jarak Tanam Dan Pupuk Organik Cair Untuk Produksi Tumpangsari Bawang Merah Dan Cabai Merah Di Lahan Pasca Erupsi Merapi. The 9th University Research Colloqium 2019 
61 / Agustrina, R., B. G. Hernawati, Yulianti, B. Irawan

Universitas Muhammadiyah

Purworejo.

Susanna, A. Ulim., Junaidi. (2009).

Pemanfaatan Kascing Untuk

Menghambat Perkembangan

Fusarium oxysporum Pada

Tanaman Tomat. Jurnal Agrista, 13(1), 137-143.
Tognetti.J.A., H.G. Pontis., G.M.A. Martinez-Noel. (2013). Sucrose signaling in plants. Plant Signaling \& Behavior, 8(3), e233161-10.

Wandani. S.A.T., Yuliani, Y.S. Rahayu. (2015). Uji Ketahanan Lima Varietas Tanaman Cabai Merah (Capsicum annuum) terhadap Penyakit Tular Tanah (Fusarium oxysporum f.sp. capsici). Lentera Bio, 4(3),155-160. 
The Effect of Magnetic ... / 62 